\title{
CONCERNING THE DEPOSITION AND DIAGENESIS OF STRATA IN POLAR FIRN
}

\author{
By Richard B. Alley \\ (Geophysical and Polar Research Center, University of Wisconsin-Madison, 1215 West Dayton Street, \\ Madison, Wisconsin 53706, U.S.A.)
}

\begin{abstract}
Depth hoar in polar firn forms when large temperature gradients act on low-density firn, but high-density firn does not develop into depth hoar. Low densities in firn may be depositional (burial of surface hoar or still-air snowfall) or diagenetic (mass loss to the free atmosphere, typically in autumn); however, diagenesis is sufficiently strong to cause significant mass loss only in the top $50-100 \mathrm{~mm}$ of firn. Between about $50-100 \mathrm{~mm}$ and $2 \mathrm{~m}$ depth, grain growth and densification are accelerated strongly by temperature-gradient effects; from 2 to $5 \mathrm{~m}$, temperature gradients have a small but measurable effect on rates of processes in firn, and below $5 \mathrm{~m}$ rates essentially have isothermal values.

Diagenetic depth-hoar layers typically develop in the autumn, are relatively thick, and have smooth bases. Depositional depth-hoar layers may develop at any season, are relatively thin, and have irregular bases. In low-accumulation regions, visual stratification may preserve only an annual signal, but in high-accumulation regions individual storms or other features may be recognizable.
\end{abstract}

\section{INTRODUCTION}

Shallow-pit studies of firn have been among the most common and useful glaciological studies for decades Among other goals, shallow-pit studies seek to identify annual layers and the processes by which such layers form and are altered. However, despite the many pit studies that have been conducted, most aspects of firn deposition and diagenesis still are not understood fully.

Here we present results of surficial observations and shallow-pit studies conducted at site A, Greenland, and at the Upstream B and ridge BC camps on the Siple Coast of West Antarctica (Fig. 1). (The ridge BC camp is also known as the Ohio State North Camp.) All three sites have similar temperatures but site $\mathrm{A}$ has a higher accumulation rate than the Upstream B or ridge $\mathrm{BC}$ camps (Table I). The results presented here form part of our ongoing study of transformations in firn and shallow ice (Alley and others, 1982; Alley, 1987a, b). We are especially interested in using pit studies to set the upper boundary condition for calculations of grain growth and densification in deeper firn and ice, and so we concentrate on the origin of strata (depositional or diagenetic) and on determining the depth at

\section{TABLE I}

Site

Upstream B, Antarctica

Ridge BC, Antarctica

Site A, Greenland

$$
\begin{gathered}
\text { Accumulation } \\
\mathrm{m} \mathrm{a}^{-1} \text { ice }
\end{gathered}
$$

Temperature

$$
0.086
$$$$
-26.4^{*}
$$

0.29 which processes internal to the firn become dominant over processes driven from the upper surface. (Notice that we follow the metallurgical convention of treating "grain" and "crystal" as synonymous terms; in this terminology, a discrete geometric entity composed of two or more grains or crystals is a "particle". Particles cannot be identified on a plane of section - full three-dimensional information is required so we deal only with grains.)

\section{STANDARD MODEL OF FIRN STRATIFICATION}

The effort to identify an annual signal by visual inspection and simple physical measurements has led to the "standard model" of firn stratification, which can trace its roots to Sorge (1935) and which has been developed by Benson (1962) and Gow (1965), among others. Briefly stated, the standard model holds that coarse-grained, low-density layers of depth hoar form near the snow surface during late summer and autumn when cold air over warm snow causes upward vapor transport, and that fine-grained, high-density wind slabs are deposited above the depth hoar in winter by strong winds. Condensation of vapor at the top of the depth hoar may cause an iced crust to form before wind-slab deposition, and other iced crusts may form in summer accumulation in response to intense insolation and high temperatures. The standard model interprets each depth-hoar/wind-slab couplet, with or without iced crusts, as the autumn and winter of one year. Such couplets can be identified visually, through measurements of grain-size, density, or hardness, or through a combination of these techniques.

The standard model has been tested extensively, by comparing annual layers identified using the model with annual layers identified from repeated inspection of accumulation stakes, from measurements of other annually varying components (microparticle concentrations, oxygen-isotopic ratios, etc.), from identification of marker horizons (especially atomic bomb fall-out horizons), and from ages determined by radiometric dating (e.g. Benson, 1962, 1971; Cameron, 1964; Giovinetto, 1964; Gow, 1965, 1968; Koerner, 1971; Picciotto and others, 1971; Palais and others, 1982; Palais, 1984; Mosley-Thompson and others, 1985). These studies generally support the standard model with certain restrictions. In regions of low accumulation and high surface relief (the central East Antarctic plateau), accumulation from an entire year may be missing from a site or enough of a year may be missing to disrupt the depth-hoar/wind-slab signal. Gow (1965) argued that such missing years leave a signal that can be interpreted, but that careful observations are required. Studies also show that much random variation, both vertical and horizontal, is imposed on the depth-hoar/wind-slab signal, so that large exposures (pit walls rather than cores) should be studied if possible (e.g. Mosley-Thompson and others, 1985). Despite these difficulties, the standard model has proven to be a valuable and reliable tool in glaciology, and we adopt it here.

However, details and elaborations of the standard model have not found such general application. At some sites, iced 

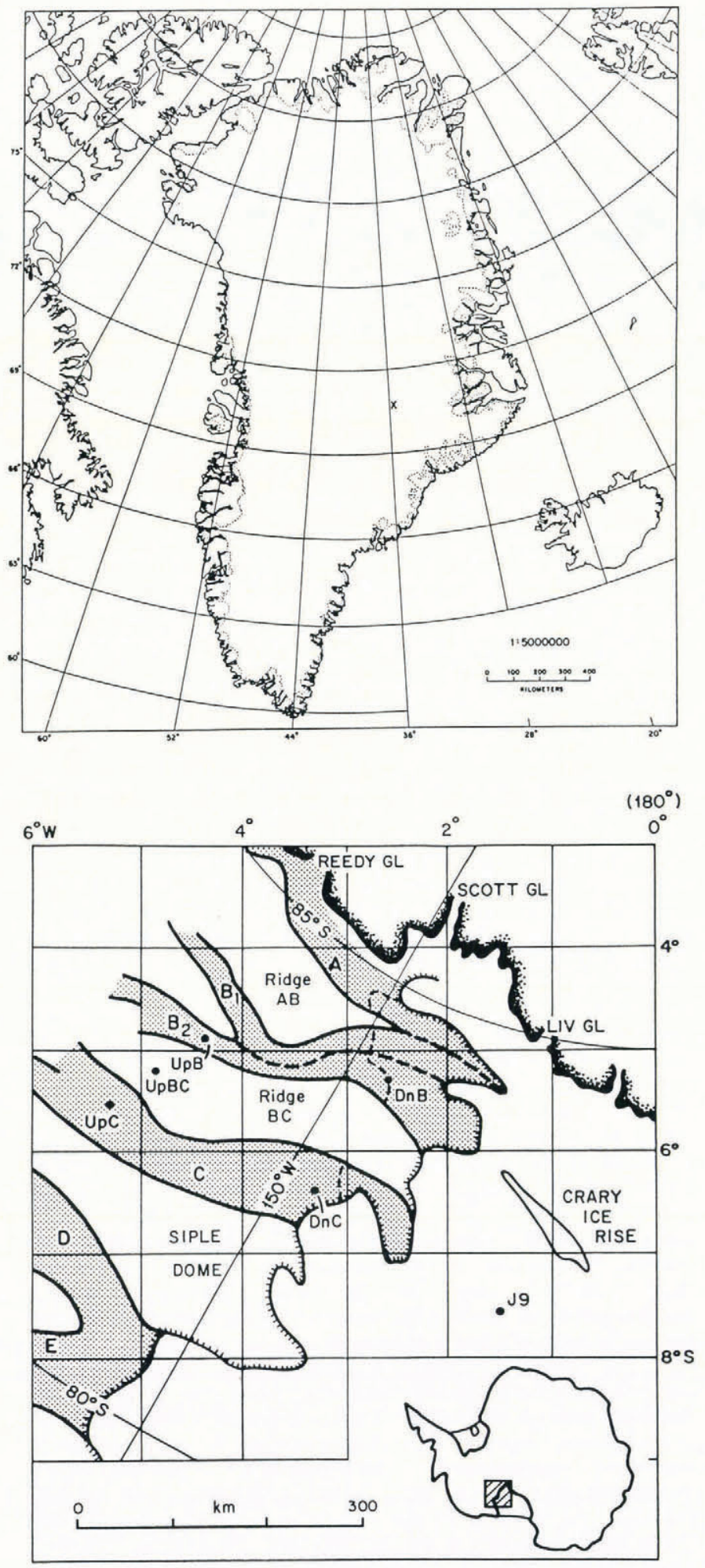

Fig. 1. Location maps for site A, Greenland ( $\times$ ) and Upstream $B(U p B)$ and ridge $B C(U p B C)$ camps, Antarctica. The Antarctic map is modified from Shabtaie and Bentley (1987).

crusts occurring in summer accumulation or immediately above depth hoar have proven more valuable than depth hoar itself in identifying annual layers (Gow, 1968, at Byrd Station; Palais and others, 1982, at Dome C), whereas at other sites (including those studied here) crusts are of little or no value. This almost certainly reflects a real difference between sites. As a second example, Koerner (1971) argued that depth hoar originates at the surface at Plateau Station, Gow (1965) observed that depth hoar forms cogenetically beneath crusts at the South Pole, Langway (1967) emphasized the importance of deposition of a cold wind slab over warm snow as a prerequisite for depth-hoar formation at Site 2, Greenland, and Palais (1984) argued that depth hoar develops over several years at Dome $\mathrm{C}$ and is not recognizable until about $300 \mathrm{~mm}$ depth. Again, most of these differences and others in the literature may be due to differences between sites, although we suspect that limited data sets and variation in definitions tend to emphasize differences that initially are not large.

Wind slabs generally preserve many attributes of their deposition, but the origin of depth hoar is more difficult to understand. Recent papers by Colbeck $(1982,1983)$ and Sommerfeld (1983) have elucidated many of the physical processes involved in the formation of depth hoar, although much work remains before a quantitative theory of depth-hoar formation emerges. Here, we briefly review the qualitative factors involved in depth-hoar formation.

Depth hoar is low-density firn or snow containing large, faceted, of ten cup-shaped crystals. Colbeck (1982) studied the origin of faceted crystals. He found that faceted crystals are growth forms rather than equilibrium forms, and only exist if crystal growth is rapid. He also found that growth in the presence of temperature gradients is limited by vapor flux, which is proportional to the temperature gradient, and that a gradient of about $10^{\circ} \mathrm{C} / \mathrm{m}$ or larger is required for growth of faceted crystals. The rapid growth of faceted crystals means that faceted crystals become coarse-grained rapidly.

These results imply that depth-hoar formation requires low-density firn, as illustrated in the branch-grain theory of Sommerfeld (1983). In this theory, grains or parts of grains receiving large vapor fluxes grow rapidly, and become faceted. Random variations ensure that a large vapor flux will cause some grains to grow rapidly while other grains disappear, even if the temperature gradient is linear and the average grain gains and loses mass at the same rate. A large local vapor flux is favored by a large temperature gradient on a scale of many grains, by large spacing between grains in the direction of the macroscopic temperature gradient (big pores), and by lack of ice-ice contacts and thus a heat-conduction path in the same direction (end-grain geometry). These in turn require low firn densities (Weller and Schwerdtfeger, 1970; Alley, 1986, 1987b).

Sommerfeld (1983) suggested that depth-hoar formation cannot occur at densities above $350 \mathrm{~kg} \mathrm{~m}^{-3}$ and becomes increasingly more likely as densities decrease; Perla and Ommanney (1985) have verified experimentally that low densities $\left(\leqslant 200 \mathrm{~kg} \mathrm{~m}^{-3}\right)$ favor depth-hoar formation and high densities suppress depth-hoar formation. This should be especially true in polar regions, where maximum thermal gradients are only about $10^{\circ} \mathrm{C} / \mathrm{m}$ in firn (Dalrymple, 1963), the lower end of gradients capable of causing growth of faceted crystals. (Bader and others (1939) argued that wind pumping may be necessary to allow sufficient vapor flux to form depth hoar.)

We thus see that low-density firn subject to temperature gradients over time will grow large, faceted crystals and become depth hoar, but that high-density firn cannot become depth hoar. The crystal size and prominence of facets will increase with temperature gradients and with time spent in them, which depends on accumulation rate (Nishimura and Maeno, 1984, 1985), but low density is a prerequisite for depth-hoar formation.

Low densities in firn can arise depositionally or diagenetically. The standard model is based on diagenetic mass loss to the free atmosphere in the autumn, but we also expect that depth hoar can form whenever still-air snowfall or surface hoar is buried rapidly enough to avoid reworking by subsequent wind storms but slowly enough to remain at depths with large temperature gradients long enough to develop large, faceted crystals. The data presented below show that depth-hoar layers do develop in such depositional low-density layers as well as in diagenetic low-density layers, but that we can distinguish the types of depth hoar based on visual observations.

\section{METHOD}

Snow-pit stratigraphy was examined using the light-pit method (Koerner, 1971). In this method, two pits separated by a wall $\leqslant 0.5 \mathrm{~m}$ thick are dug at a site and one is covered with plywood. Light entering the open pit illuminates the 
intervening wall, allowing the observer in the closed pit to map the stratigraphy in great detail. We supplemented detailed mapping with photographs. Less-detailed mapping was conducted on the side and back walls of each closed pit. At site $A$ and ridge $B C$, we removed the thin wall between pits after mapping, covered the entire resulting large pit, and used it as a core-processing laboratory; less-detailed mapping was extended over this large pit. All pits were $2 \mathrm{~m}$ deep, and horizontal dimensions mapped were about $2 \mathrm{~m}$ by $2 \mathrm{~m}$ at Upstream $\mathrm{B}, 2 \mathrm{~m}$ by $5 \mathrm{~m}$ at site $\mathrm{A}$, and $2 \mathrm{~m}$ by $7 \mathrm{~m}$ at ridge $\mathrm{BC}$.

Bulk densities were measured using snow-density tubes and a triple-beam balance, and tubes were placed with regard to strata. Thin sections and polished sections were prepared from blocks of firn soaked in supercooled dimethyl phthalate (Perla, 1982) and frozen. Contrast was enhanced by coloring each section with a permanent marker, which soaks into the filler but beads off of the ice (personal communication from K. Beatley, 1984). Thin sections were photographed both in reflected light (to provide truly two-dimensional data) and in transmitted light between crossed polarizing filters. Grain boundaries were marked carefully on the reflected pictures, based on three lines of evidence. First, exposure of sections to the free atmosphere before coloring allows thermal grooves to form, and these are visible in photographs under favorable circumstances. Secondly, pictures taken between crossed polarizing filters show grain boundaries clearly. In very fine-grained firn (typically, wind slabs in the upper meter) different grains are too small to provide contrast between crossed polarizing filters. Then, if etching does not bring out grain boundaries clearly, geometric criteria must be used. Kry (1975) argued that there is a one-to-one correspondence between grain boundaries and constricted intergranular necks in snow. We have compared grain boundaries in fine-grained firn determined from etching and from this geometric criterion, and find good general agreement, but identification of grains in the upper $1 \mathrm{~m}$ should be considered less accurate than in coarser-grained material from greater depth. Stereologic parameters were measured from the marked, reflected-light pictures using standard techniques (see Underwood, 1970), which we have summarized elsewhere (Alley, 1987b, unpublished).

\section{OBSERVATIONS}

\section{Surface processes}

Pit stratification cannot be understood without reference to surface processes. Our observations of surface evolution, summarized below, largely repeat those of Gow (1965) at the South Pole, and we recommend that paper for further information.

Under calm conditions, snowfall forms a soft, sometimes coarse-grained layer of bulk density as low as $200 \mathrm{~kg} \mathrm{~m}^{-3}$ or less. Under windy conditions, snow grains are broken and rounded by transport and form a fine-grained, hard wind slab of bulk density up to $400 \mathrm{~kg} \mathrm{~m}^{-3}$ or more. If accumulation is significant, the upper surface of the new snow is usually relatively smooth even under windy conditions.

Formation of sastrugi (dunes, or features of high relief) is favored by high winds and light or no snowfall, when the ability of wind to transport snow exceeds the snow supply, but when some snow transport is occurring. Under such conditions, much of the snow surface is scoured clean and flat, and suffers neither erosion nor deposition; wind crusts probably form at such surfaces (Gow, 1965; this study). If a surface irregularity interrupts snow transport under such conditions, deposition of a dune will result. The dune may remain pinned to the obstacle that started it or may migrate down-wind. Snow dunes sometimes form barchans and other sand-dune forms, but most commonly they form elongated "whalebacks", typically meters long and up to $\frac{1}{2} \mathrm{~m}$ high. When wind speeds decrease, such dunes sinter rapidly into hard features of positive relief. After sintering, dunes form obstacles to subsequent winds and are eroded preferentially. Wind erosion of dunes typically produces scoops and hollows with sides locally vertical or overhanging.

Dunes and eroded dunes are believed to be ablated faster than adjacent flat areas, because dunes are more exposed to wind and sun (Gow, 1965; Weller, 1969). In addition, accumulation from snowfall or surface hoar is typically thicker between dunes than on dunes. Thus, both erosion and deposition tend to smooth the snow surface, but only deposition preserves dunes in the stratigraphic record. Both erosion (Gow, 1965; Benson, 1971) and deposition (see below) occur; I.M. Whillans and M. Strobel (manuscript in preparation) will be presenting data that bear on their relative importance.

\section{Depth-hoar formation}

Pit-wall maps and associated data are shown in Figures 2 and 3 for site A, Greenland, and Upstream B and ridge

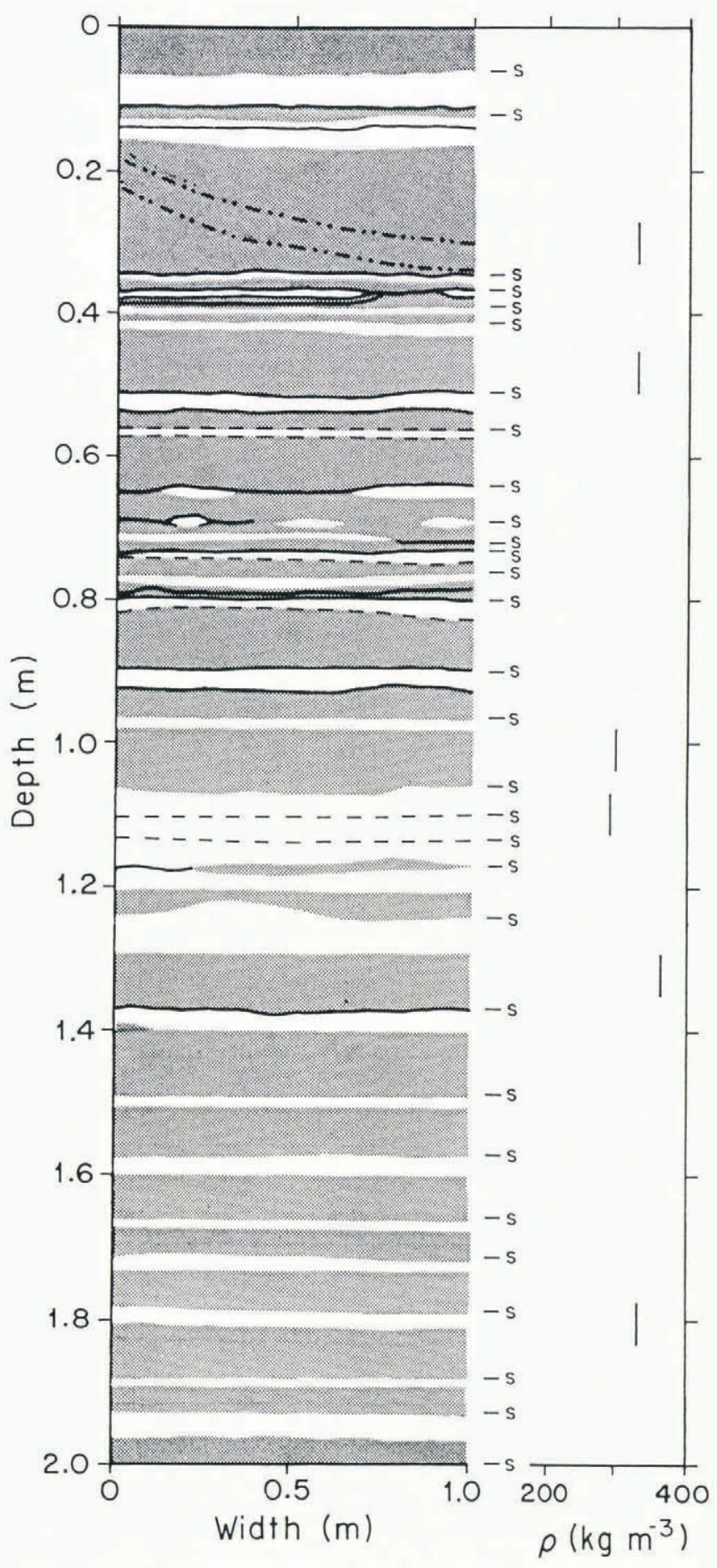

Fig. 2. Pit map, site A, Greenland. Fine- and mediumgrained firn are shown stippled, whereas coarse-grained firn is shown white. Crusts are dark lines, intermittent or unclear crusts are dashed, and cross-bedding in sastrugi is indicated with a dot-dash pattern. The pit wall shown trends nearly north-south, with north on the right. (From Alley and Koci, 1988.) 


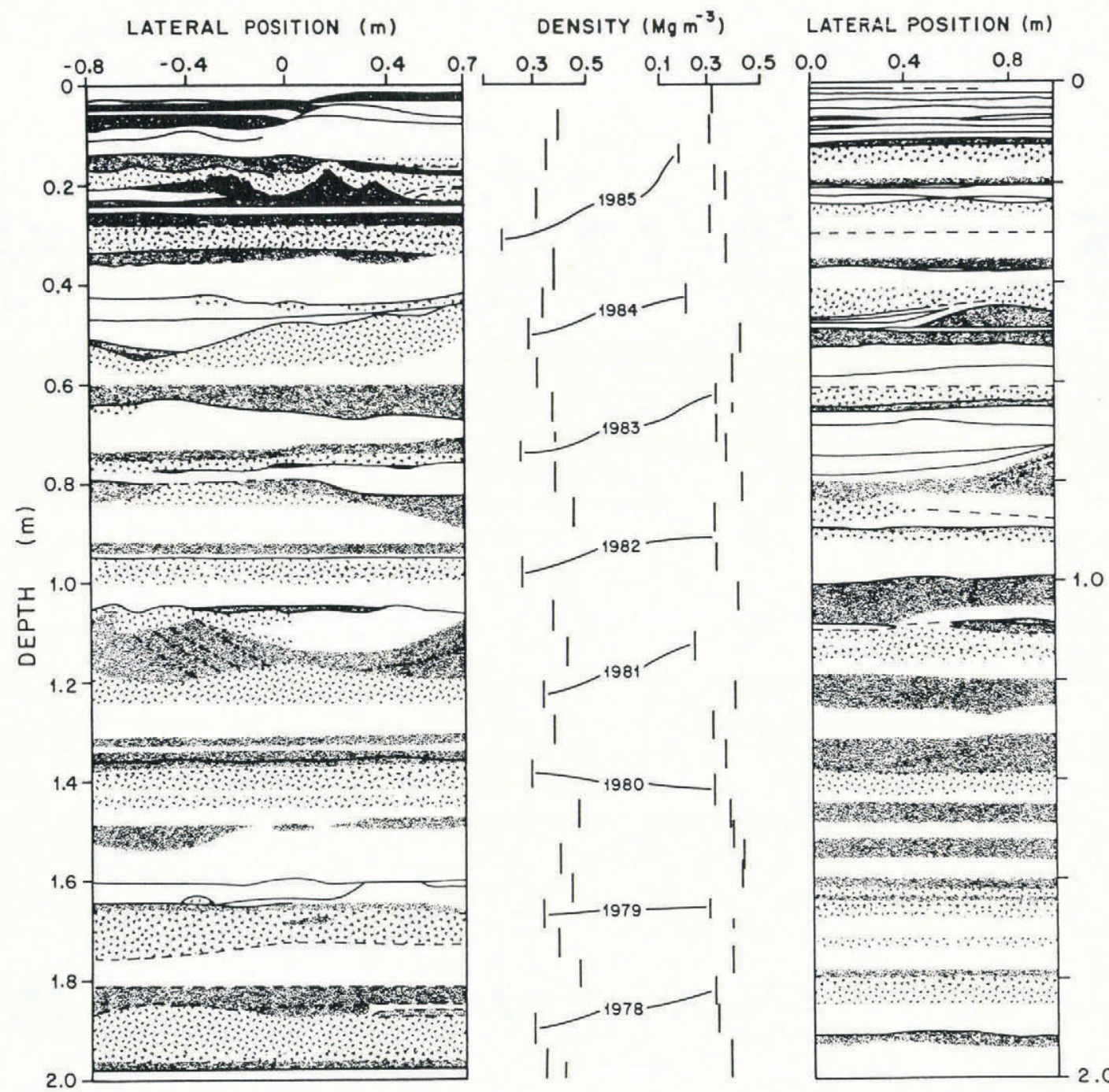

Fig. 3. Pit maps for Upstream B (left) and ridge BC (right), Antarctica. Crusts are indicated as in Figure 2. The dark stippled pattern indicates fine-grained firn, white space indicates medium-grained firn, the random dashed pattern indicates coarse-grained firn or weakly developed depth hoar, and the random " $\nu$ " pattern indicates well-developed hoar. The Upstream B pit map has grid north-east on the right; both ice flow and mean summer wind direction are out of the page towards the reader. The ridge $B C$ pit map has grid north-west on the left; mean summer wind direction is parallel to the pit wall from left to right.

BC, Antarctica. (For further information on these sites, see Alley, unpublished; Alley and Bentley, in press; Alley and Koci, 1988.) In all three cases an annual signal is visible. Comparison of observations by at least three different workers at each site found general agreement on identification of the annual signal at all three sites, with the maximum possible difference of 2 years $(9$ versus 11 years in $2 \mathrm{~m}$ ) at Upstream B.

At site $\mathrm{A}$, the stratigraphic interpretation gives a 2 year average of $0.36 \mathrm{~m} \mathrm{a}^{-1}$ of ice $\left(0.33 \mathrm{~m} \mathrm{a}^{-1}\right.$ of water), compared with a 202 year average of about $0.29 \mathrm{~m} \mathrm{a}^{-1}$ of ice based on the identification of a volcanic horizon (Alley and Koci, 1988; Clausen and others, 1988) and a value of about $0.30 \mathrm{~m} \mathrm{a}^{-1}$ of ice estimated from interpolation of accumulation values from other pit studies (Robin, 1983). At Upstream B and ridge BC, the stratigraphic interpretations shown in Figure 3 give accumulation rates of $0.086 \mathrm{~m} \mathrm{a}^{-1}$ and $0.090 \mathrm{~m} \mathrm{a}^{-1}$, respectively, each averaged over 7 years; these values are identical (to two significant figures) to values determined by locating the 1965 atomic bomb fall-out horizon (Whillans and Bindschadler, in press). These agreements are as good as, or better than, we can expect generally, given the short time spans covered by the stratigraphic analyses and the errors inherent in all methods; this gives us substantial confidence that our stratigraphic interpretations are essentially correct.

We also note that the annual signal does not account for all of the variation in the pit walls. At site A, the most striking feature is the presence of graded beds, with upward coarsening within each bed. Figure 2 shows about 30 such beds in the accumulation from 2 years (Alley and Koci, 1988). Each bed typically rests on a scoured surface that may be crusted and may truncate deeper bedding. Each bed consists of a wind slab or fine-grained firn at the base and depth hoar or coarse-grained firn at the top; the contact between fine and coarse firn is generally, but not always, gradational.

Based on appearance alone, one might suppose that each graded bed represents a storm. Fortunately, we were able to confirm this supposition by watching the formation of one graded bed. When we reached site A, in June 1985, a storm was in progress with estimated wind speeds in excess of $13 \mathrm{~m} / \mathrm{s}(45 \mathrm{~km} / \mathrm{h})$ and with some accumulation. After $2 \mathrm{~d}$, this produced a hard, dense, fine-grained wind slab about $40 \mathrm{~mm}$ thick. We placed accumulation stakes after the storm abated to monitor subsequent events. A period of sunny weather with warm days $\left(\sim-10^{\circ} \mathrm{C}\right)$ and cool nights $\left(\sim-25^{\circ} \mathrm{C}\right)$ followed, and $10-20 \mathrm{~mm}$ of surface hoar was deposited. In addition, visual examination of the upper $10 \mathrm{~mm}$ of the wind slab indicated that it had experienced some coarsening and mass loss. Next, a snowfall under warm, calm conditions deposited a coarse, low-density, $10 \mathrm{~mm}$ thick layer of stellar flakes. This was followed by a second wind storm with estimated wind speeds in excess of $22 \mathrm{~m} / \mathrm{s}(80 \mathrm{~km} / \mathrm{h})$ and some accumulation, which deposited a $40 \mathrm{~mm}$ thick wind slab of density $400-450 \mathrm{~kg} \mathrm{~m}^{-3}$. In some 
places, most or all of the surface hoar and light snow was eroded, whereas in other places their entire thickness was preserved. After a few days, the contact between the two wind slabs was traceable through a series of shallow pits as a wind crust in some places and as a coarse-grained, low-density layer in other places. The contact between the surface hoar and light snow in the low-density layer was no longer pronounced, and the surface hoar was losing its dendritic pattern but retaining crystal faces; that is, the surface hoar appeared to be transforming to depth hoar. Also, a second surface-hoar layer was forming on top of the second wind slab.

The wind-slab/surface-hoar couplet that formed during our observations appeared very similar to the graded beds observed in the pit wall. Most (but not all) of the coarse and hoar layers in the pit were more continuous than the one observed forming, but few of the wind slabs in the pit were as dense as the second one observed forming. Discontinuous depth-hoar layers in the pit were connected laterally by wind crusts, just as in the newly formed example. We therefore believe that the graded beds observed in the pit at site A represent wind storms followed by surface-hoar growth, still-air snowfall, and/or coarsening and mass loss near the tops of the wind slabs.

Support for this model comes from studies of dust, acidity, and other parameters in pits and cores by Hammer (1985). He reported 15 to 16 accumulation events per year for Crête, which is near site $A$, and presented a figure relating accumulation per storm to annual accumulation which predicts about 15 storms per year at site A, in excellent agreement with our observation of 15 storms per year.

The standard model must be modified slightly for application to site A. A cycle is visible in the pit and deeper cores in which the ratio of hoar thickness to total thickness in graded beds varies from nearly zero to nearly one and back. Based on position relative to the summer snow surface during our field season, we interpret the zone of abundant depth hoar to be late summer to autumn and the zone of sparse depth hoar to be winter; spring and early summer show greater variability.

Our observations at site A thus indicate that storms and accumulation occur year-round, but that late-summer and autumn snow undergo more diagenetic mass loss and/or are coarser-grained and lower-density at deposition than winter snow; based on our understanding of the standard model, we believe that the differences between late-summer and winter snow are more diagenetic than depositional. After allowing for the annual cycle, the relative abundances of coarse-grained and fine-grained firn do not change downward in the pit or in shallow cores, so the identity of firn must be fixed very near the surface (upper $50-100 \mathrm{~mm}$ ). The observation that storm events as thin as $50 \mathrm{~mm}$ or less are recognizable as graded beds with fine firn at their bases even after strong autumnal diagenesis also shows that diagenetic mass loss and the initiation of depth hoar are limited to the upper few tens of millimeters. In addition, our observations indicate that the low densities required for depth-hoar formation can be caused by deposition, diagenesis, or a combination of these processes.

Observations on the Siple Coast both support and expand on these results from site A. Depth hoar on the Siple Coast generally is better developed (i.e. lower density, larger grains, more crystal faces, thicker layers) than depth hoar at site A, probably because the lower accumulation rate on the Siple Coast allows firn to spend longer in the region of strong temperature gradients than at site A (Nishimura and Maeno, 1984, 1985). Two types of depth hoar can be identified on the Siple Coast. Depth-hoar layers of the first type, which we interpret to be the annual layers of the standard model, are characterized by relatively smooth lower boundaries and great thickness $(\sim 50 \mathrm{~mm})$, and frequently occur immediately beneath crusts; the lowest densities and coarsest grains occur near but below layer tops.

One of the most interesting annual depth-hoar layers occurs at about $0.5 \mathrm{~m}$ depth in the Upstream B pit (Fig. 3). The layer is developed along the top of a buried, undissected dune that thins from 0.2 to $0.1 \mathrm{~m}$ down-wind (out of the plane of the pit map in Figure 3) along the $2 \mathrm{~m}$ length of the pit. Faint cross-bedding can be observed in the dune, especially near the bottom, but it is not as well-defined as cross-bedding in other buried dunes. The base of this dune is comparable to or slightly coarser and of lower density than other dunes and wind slabs in the pit, but density decreases and grain-size increases markedly upward in the dune; the depth-hoar layer at the top is as low-density and almost as coarse-grained as other annual depth-hoar layers in the pit. The thickness, density, and grain-size of this depth-hoar layer do not vary significantly down-wind, although the overlying fine-grained layer thickens by almost $0.1 \mathrm{~m}$ down-wind.

From these observations, it is evident that this depth-hoar layer formed by diagenesis of snow deposited in a dune. Comparison of the lower part of this dune with other wind slabs not immediately adjacent to depth-hoar layers shows that it has not gained mass from the depth-hoar layer, and may have lost a small amount of mass. Density comparison between the top $50 \mathrm{~mm}$ and bottom $50 \mathrm{~mm}$ in the thicker part of the dune then indicates that the upper part has lost at least $25 \%$ of its mass, probably upward to the atmosphere. Coarsening of grains and development of growth facets may have been concurrent with or subsequent to this mass loss. Surface hoar or low-density snowfall may have contributed to formation of the upper part of the depth hoar, but are not required to explain the depth hoar and are insufficient by themselves to have formed it.

Other annual layers indicate similar processes. Because mass loss can occur from the sides as well as from the tops of features of positive relief, low-density layers of diagenetic origin should have bases as smooth as, or smoother than, their tops. On the other hand, low-density layers of depositional origin tend to fill in low spots, and so should have tops smoother than bases. The smoothness of the bases of all depth-hoar layers identified as annuil on the Siple Coast is consistent with a diagenetic orizio, at least for the lower parts of the layers, but it would be highly unlikely if the layers were depositional (see below). In some cases, the tops of the annual depth-hoar layers are truncated by wind scours, which indicates a very shallow or surficial origin for these layers. The common, but not universal, occurrence of densities increasing upward in the upper $10-20 \mathrm{~mm}$ of annual depth-hoar layers, of ten leading up to a crust, is consistent with some condensation (+ surface-hoar growth ?) at the surface and fastest mass loss just below the surface. Typical thicknesses of $50 \mathrm{~mm}$ for annual depth-hoar layers may then indicate the maximum depth to which strong mass loss can occur in a single autumn. If accumulation occurs during the autumn when upward mass loss is strongest, the mass-loss process will be interrupted and will begin again at the new snow surface. This will cause the annual depth-hoar layer to consist of two or more coarsening-upward, coarse-grained graded beds. Such strata are well-developed at site A, where the accumulation rate is high and autumnal accumulation events are common (Fig. 2, $1.1 \mathrm{~m}$ ) and occur occasionally on the Siple Coast, where autumnal accumulation events must be less common (e.g. Fig. 3, Upstream B, $1.4 \mathrm{~m}$ ).

Before considering the second type of depth-hoar layers, a brief digression on crusts is warranted here. Crusts at Upstream B and ridge BC are generally less than $0.5-1.0 \mathrm{~mm}$ thick, and are typically one grain thick. They are not strongly iced, with densities of about $400 \mathrm{~kg} \mathrm{~m}^{-3}$ near the surface based on thin-section measurements. They therefore resemble the wind crusts reported by Gow (1968) at Byrd Station more than the various iced crusts reported there. Only the common occurrence of crusts above depth hoar suggests a possible origin from condensation and/or radiation, but wind action cannot be ruled out for such crusts. Also, the association of depth hoar and crusts is far from absolute. Depth-hoar layers occur with single crusts above, with crusts above and below, and without crusts. In one case at Upstream B, a crust follows the top of a depth-hoar layer for some distance and then rises away from it as fine-grained firn intervenes. Crusts also occur totally unrelated to depth hoar. Cross-beds in dunes are marked by faint crusts. Abundance of crusts decreases downward in the upper $2 \mathrm{~m}$, probably due to diagenesis. (Firn near crusts densifies more rapidly than crusts do, reducing the density contrast by which crusts are recognized, and grain re-arrangement during densification on 
a scale of one grain (Alley, 1987a) tends to disrupt crusts.)

The second sort of depth hoar occurs in irregular or discontinuous layers typically $20 \mathrm{~mm}$ thick or less. In at least two cases at Upstream B (near 0.2 and $1.1 \mathrm{~m}$; Fig. 3), such depth-hoar layers rest on eroded sastrugi that appear identical to eroded sastrugi observed at the surface. The upper surfaces of these depth-hoar layers are generally sub-parallel to the lower surfaces but are smoother. Vertical lineation in such layers (discussed further below) is normal to the lower surface or between surface-normal and vertical rather than vertical. Virtual voids occur in these depth-hoar layers immediately adjacent to the steepest or overhanging parts of the underlying sastrugi. Crusts commonly occur above these depth-hoar layers.

These depth-hoar layers are certainly depositionally controlled. The sharpness of underlying sastrugi and thinning of depth hoar over sastrugi crests are inconsistent with mass loss from denser snow. In addition, we believe it is likely that these layers originated as surface hoar. Our observations of summer surface hoar on the Siple Coast show that it is typically $10-20 \mathrm{~mm}$ thick, thins over crests of sastrugi which may remain sharp, has lineation normal to the surface on which it grows or between normal and vertical, and is sparse or absent in pockets against steep or overhanging sastrugi faces where radiative cooling is reduced. One surface-hoar layer grew at ridge BC in a week to $10-20 \mathrm{~mm}$ thick, and developed a discontinuous thin crust on top in response to one very light snowfall and several days of warm temperatures $\left(-10^{\circ} \mathrm{C}\right)$ and bright sun. Although this surface hoar had low density (estimated at $\left.150 \mathrm{~kg} \mathrm{~m}^{-3}\right)$, it was developing some mechanical strength after a week.

Two further points regarding the Siple Coast pit maps deserve mention here. First, the shallowest annual depth-hoar layers at Upstream $B$ and ridge BC were less than a year old when observed, but were characterized by low density, coarse grains, abundant crystal faces, and cup-shaped crystals; in short, they exhibited all the characteristics of well-developed depth hoar after less than 1 year. Secondly, if depth hoar formed at some significant depth (>200-300 $\mathrm{mm}$ ) below the surface, we would expect the vertical frequency of depth-hoar layers to increase downward. However, just as at site $A$, the frequency of depth-hoar layers (or any other layers) in any vertical increment does not increase downward after allowing for densification.

Based on data from site $A$ and the Siple Coast, we therefore argue that depth hoar develops in low-density layers formed by still-air snowfall or surface-hoar deposition, by mass loss to the free atmosphere, especially in the autumn, or by a combination of these processes. Diagenetically controlled depth-hoar layers form annually, are relatively thick, and have smooth lower surfaces. Depositionally controlled depth-hoar layers form at any time of the year, are relatively thin, and may have rough lower surfaces. The transformation of surface hoar to depth hoar can proceed significantly in a week, and well-developed depth hoar less than a year old is common. The identity of a layer (depth hoar, wind slab, crust, etc.) is fixed by deposition and very shallow diagenesis (roughly the upper $50-100 \mathrm{~mm}$ ); deeper processes act to alter layers and generally reduce the contrast between them, but are not potent enough to change one type of firn to another.

The work of I.M. Whillans and M. Strobel (manuscript in preparation) generally confirms this model, although some differences are evident. Whillans and Strobel studied the lateral continuity of layers over tens of meters near the Upstream B and ridge BC camps; observations were made in single pits without benefit of back-lighting from adjacent pits, although a board was placed over the section of pit wall being observed to allow some back-lighting through the adjacent snow surface. They observed that the lateral continuity of depth-hoar layers increases with depth in the upper tenths of a meter and that layers are essentially continuous below about $1 \mathrm{~m}$; discontinuities in the shallow firn have a wavelength similar to the sastrugi wavelength. Where shallow depth hoar is present, the vertical spacing between depth-hoar layers does not change significantly with depth. These observations suggest that actual development of depth hoar may occur over a few years and at a variable rate that may be related to surface sastrugi; however, development of depth hoar at depth occurs along depositional strata. Thus, the development of a firn layer into depth hoar is made possible by the burial of low-density firn, but the development of this low-density firn into depth hoar may depend on temperature-gradient processes that may exhibit variable rates.

It is also possible that Whillans and Strobel used slightly different criteria than the present study to identify depth hoar, so that the differences in observed lateral continuity are semantic rather than physical, or that their less-sensitive observational technique failed to identify some depth hoar. At ridge $\mathrm{BC}$, we traced the prominent depth-hoar layer at about $150 \mathrm{~mm}$ depth (Fig. 3) for $7 \mathrm{~m}$ by $2 \mathrm{~m}$ in the pit, and then found a similar prominent depth-hoar layer at a similar depth at every one of a dozen sampling points spread over hundreds of meters, suggesting significant lateral continuity for that shallow layer.

\section{Diagenesis}

We have determined that the nature of a firn layer is fixed by deposition and by diagenesis in the upper $50-100 \mathrm{~mm}$. We now use data from deeper firn to show that firn diagenesis is affected strongly by meteorologic processes to about $2 \mathrm{~m}$ depth, and is affected weakly to about $5 \mathrm{~m}$ depth. Many of the data presented here have been discussed more fully by Alley (1987b, unpublished).

One of the most important results is evident from careful inspection of Figure 3, which shows that density variations between layers near any depth are largest near the surface and decrease with depth, a trend that is significant at the $90 \%$ confidence level (Alley and Bentley, in press). Depth-hoar layers exhibit their lowest density in their first year and then densify more rapidly than other firn types in succeeding years. This demonstrates that the development of the low densities of depth-hoar layers cannot occur at significant depths $(\geqslant 100-200 \mathrm{~mm})$. This also causes visible stratification to become less distinct with increasing depth.

A second interesting result is shown by Figure 4, from Alley and Bentley (in press), which shows the average number of contacts per grain (the coordination number) plotted against density for all three sites considered here and for various types of firn. Densities are known to within $5 \%$ or better. Errors in coordination number cannot be known exactly because of assumptions in the model used

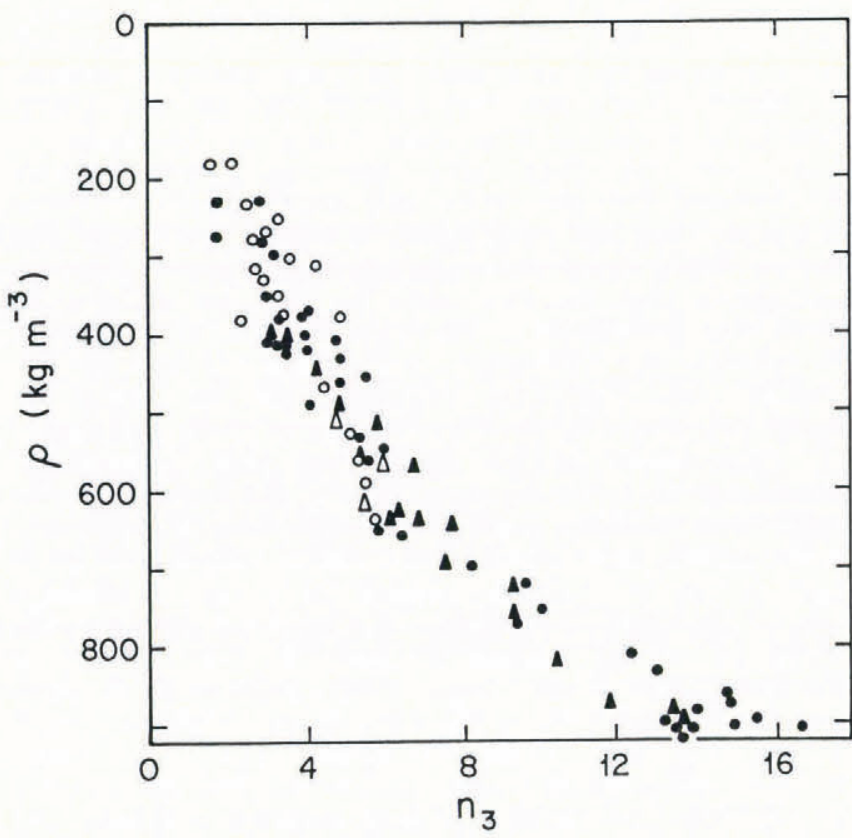

Fig. 4. Average coordination number, $n_{3}$, plotted against relative density ( $=$ volume fraction of ice), $\rho$, for samples from site $A$ (triangles) and Upstream $B$ and ridge $B C$ (circles). Coarse-grained firn and depth hoar are indicated by open symbols; fine-grained and medium-grained firn are indicated by solid symbols. In anisotropic firn from shallow depths, all measurements were made in sections cut vertically. 
to estimate the coordination number (Alley, 1986), but we believe values are within $20 \%$ and are more accurate for fine-grained firn and for deeper firn than for depth hoar in the upper $2 \mathrm{~m}$. Figure 4 shows that the connectivity of grains increases with density and that any difference in connectivity between types of firn at a given density is masked by measurement error. At least to a first approximation, then, connectivity is determined by density. Thus, our contention that depth hoar can develop only in low-density firn is equivalent to the contention of Sommerfeld (1983) that depth hoar can develop only if connectivity is low.

Another important point is illustrated by Figure 5, which shows the vertical anisotropy of ice-air surfaces, $\omega_{f}$.

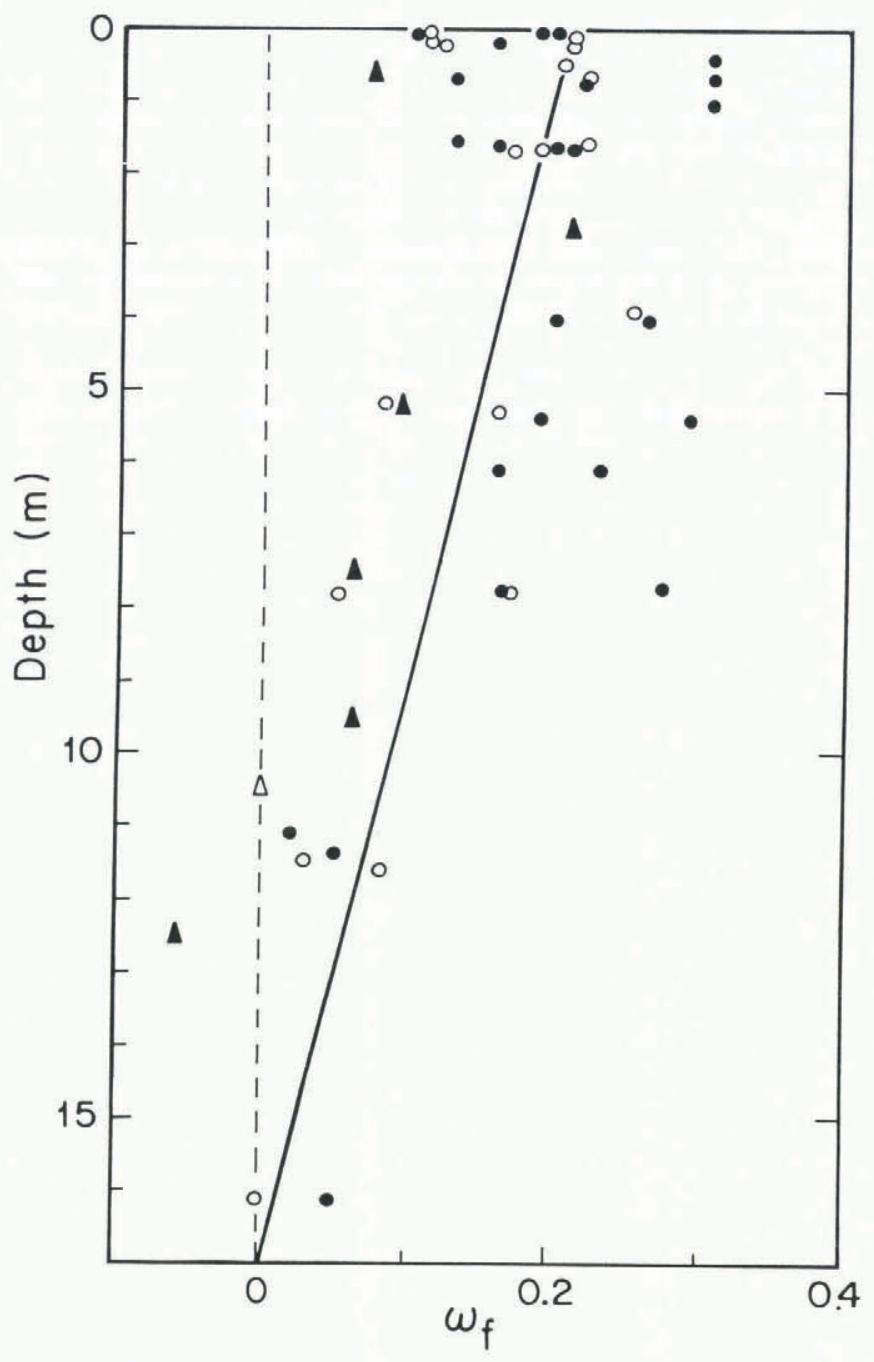

Fig. 5. Vertical anisotropy of ice-air surface, $\omega_{f}$, plotted against relative density ( $=$ volume fraction of ice), $\rho$, for samples from site $A$ (triangles), and Upstream $B$ and ridge $B C$ (circles). Coarse-grained firn and depth hoar are indicated by open symbols; fine-grained and medium-grained firn are indicated by solid symbols. Isotropic firn plots on the dashed line at $\omega_{f}=0$. The regression line for all points plotted is shown. Errors in determination of $\omega_{f}$ vary somewhat between samples, but are typically \pm 0.05 to \pm 0.10 .

(An isotropic material has $\omega_{\mathrm{f}}=0$, and a system in which all surfaces are oriented vertically has $\omega_{\mathrm{f}}=1$; Alley, 1987b.) This quantity is highly variable, although different types of firn seem to have similar values. Vertical anisotropy develops quite rapidly, is highest in the top $2 \mathrm{~m}$, and decays rapidly below about $5 \mathrm{~m}$. Vertical anisotropy arises from vertical vapor transport in response to atmospheric forcing. The high value of anisotropy in the upper $2 \mathrm{~m}$ and the rapid decay below $5 \mathrm{~m}$ shows that atmospheric forcing is strongest in the upper $2 \mathrm{~m}$ and has negligible effect below about $5 \mathrm{~m}$.
Grain-growth curves yield a similar result. Plots of grain-size against depth and age (e.g. Gow, 1968; Alley and Koci, 1988; Alley and Bentley, in press) show that grain growth occurs at the isothermal rate below $5 \mathrm{~m}$ depth and at a much accelerated rate above $2 \mathrm{~m}$ depth where temperature-gradient effects are large; the grain-growth rate between 2 and $5 \mathrm{~m}$ is slightly accelerated from the isothermal rate in some cases but is virtually identical in other cases. Densification is also fastest in the upper $2 \mathrm{~m}$, although the bonds between grains are as large as in deeper firn (Alley, unpublished) and the load is small; meteorologic forcing probably contributes to this rapid densification at shallow depth.

\section{CONCLUSIONS}

Based on the data and discussion presented above, we can now draw certain conclusions about the origin and diagenesis of polar firn. The basic nature of firn whether it is a wind slab or depth hoar - is determined by depositional processes and by diagenesis in the upper 50-100 mm. Wind slabs, surface hoar, and intermediate types of firn can be deposited and buried. If subjected to vapor transport down temperature gradients, buried low-density, low-connectivity layers will develop into depth hoar, but high-density layers will not. High-density layers can develop into depth hoar only if they suffer significant mass loss to the free atmosphere, which can occur only while they are in the upper $50-100 \mathrm{~mm}$; this process seems to occur in the late summer or autumn.

Between about $100 \mathrm{~mm}$ and $2 \mathrm{~m}$ depth, preservation of strong vertical anisotropy and rapid grain growth show that processes from the free surface affect the firn significantly, although such processes are not vigorous enough to change the fundamental nature of the firn. Meteorological processes diminish rapidly in importance below $2 \mathrm{~m}$ and have essentially no effect below $5 \mathrm{~m}$. Thus, measurements below $5 \mathrm{~m}$ reveal the isothermal rates of processes in firn, and measurements below $2 \mathrm{~m}$ provide a reasonable approximation of isothermal rates.

Because visible stratification is determined by conditions at the time of deposition and by very shallow diagenesis, it provides a good record of atmospheric forcing. The period of atmospheric forcing recorded depends on the accumulation rate. In low-accumulation regions, only the annual depth hoar formed by mass loss to the atmosphere during the autumn may be recognizable, whereas in high-accumulation regions individual storms may be preserved.

\section{ACKNOWLEDGEMENTS}

We thank personnel from the Polar Ice Coring Office (W. Boller, B. Koci, K. Kuivinen, J. Litwak, and K. Mountain) for ice-core drilling; I.M. Whillans and $M$. Strobel for access to unpublished data; C.R. Bentley and A.J. Gow for helpful suggestions; and A.N. Mares and S.H. Smith for manuscript and figure preparation. This work was supported by the U.S. National Science Foundation, Division of Polar Programs, under grants DPP83-15777, DPP85-20846, and DPP85-21038 to the University of Wisconsin Geophysical and Polar Research Center, and grant DPP83-18528 to the Polar Ice Coring Office. This is contribution No. 469 of the Geophysical and Polar Research Center, University of Wisconsin-Madison.

\section{REFERENCES}

Alley, R.B. 1986. Three-dimensional coordination number from two-dimensional measurements: a new method. $J$. Glaciol., 32(112), 391-396.

Alley, R.B. 1987a. Firn densification by grain-boundary sliding: a first model. J. Phys. (Paris), 48, Colloq. C1, 249-254. (Supplément au 3.)

Alley, R.B. 1987b. Texture of polar firn for remote sensing. Ann. Glaciol., 9, 1-4.

Alley, R.B. Unpublished. Transformations in polar firn. (Ph.D. thesis, University of Wisconsin-Madison, 1987.) 
Alley, R.B. and C.R. Bentley. 1988. Ice-core analysis on the Siple Coast of West Antarctica. Ann. Glaciol., 11.

Alley, R.B. and B.R. Koci. 1988. Ice-core analysis at site A, Greenland: preliminary results. Ann. Glaciol., 10, 1-4.

Alley, R.B., J.F. Bolzan, and I.M. Whillans. 1982. Polar firn densification and grain growth. Ann. Glaciol., 3, 7-11.

Bader, H., R. Haefeli, E. Bucher, J. Neher, O. Eckel, and C. Thams, 1939. Der Schnee und seine Metamorphose. Beitr. Geol. Schweiz, Geotech. Ser. Hydrol., 3. [English Translation: SIPRE Transl. 14, 1954.]

Benson, C.S. 1962. Stratigraphic studies in the snow and firn of the Greenland ice sheet. SIPRE Res. Rep. 70.

Benson, C.S. 1971. Stratigraphic studies in the snow at Byrd Station, Antarctica, compared with similar studies in Greenland. In Crary, A.P., ed. Antarctic snow and ice studies II. Washington, D.C., American Geophysical Union, 333-353. (Antarct. Res. Ser. 16.)

Cameron, R.L. 1964. Glaciological studies at Wilkes Station, Budd Coast, Antarctica. In Mellor, M., ed. Antarctic snow and ice studies. Washington, DC, American Geophysical Union, 1-36. (Antarct. Res. Ser. 2.)

Clausen, H.B., N.S. Gundestrup, S.J. Johnsen, R. Bindschadler, and J. Zwally. 1988. Glaciological investigations in the Crête area, central Greenland: a search for a new deep-drilling site. Ann. Glaciol., 10, 10-15.

Colbeck, S.C. 1982. Growth of faceted crystals in a snow cover. CRREL Rep. 82-29.

Colbeck, S.C. 1983. Theory of metamorphism of dry snow. J. Geophys. Res., 88(C9), 5475-5482.

Dalrymple, P.C. 1963. South Pole micrometeorology program. Part 2. Data analysis. Natick, MA, U.S. Quartermaster Research and Engineering Center. (Tech. Rep. ES7.)

Giovinetto, M.B. 1964. The drainage systems of Antarctica: accumulation. In Mellor, M., ed. Antarctic snow and ice studies. Washington, DC, American Geophysical Union, 127-155. (Antarct. Res. Ser. 2.)

Gow, A.J. 1965. Snow studies in Antarctica. CRREL Res. Rep. 177.

Gow, A.J. 1968. Deep core studies of the accumulation and densification of snow at Byrd Station and Little America V, Antarctica. CRREL Res. Rep. 197.

Hammer, C.U. 1985. The influence on atmospheric composition of volcanic eruptions as derived from ice-core analysis. Ann. Glaciol., 7, 125-129.

Koerner, R.M. 1971. A stratigraphic method of determining the snow accumulation at Plateau Station, Antarctica, and application to South Pole-Queen Maud Land traverse 2, 1965-1966. In Crary, A.P., ed. Antarctic snow and ice studies II. Washington, DC, American Geophysical Union, 225-238. (Antarct. Res. Ser. 16.)

Kry, P.R. 1975. Quantitative stereological analysis of grain bonds in snow, J. Glaciol., 14(72), 467-477.

Langway, C.C., jr. 1967. Stratigraphic analysis of a deep ice core from Greenland. CRREL Res. Rep. 77.

Mosley-Thompson, E., P.D. Kruss, L.G. Thompson, M. Pourchet, and P. Grootes. 1985. Snow stratigraphic record at South Pole: potential for paleoclimatic reconstruction. Ann. Glaciol., 7, 26-33.

Nishimura, H. and N. Maeno. 1984. Snow structure and depth hoar formation in Mizuho Plateau, Antarctica. Mem. Natl. Inst. Polar Res. Spec. Issue 34, 137-146.

Nishimura, H. and N. Maeno. 1985. Studies on structures and physical properties of snow in Mizuho Plateau, Antarctica. Ann. Glaciol., 6, 105-107.

Palais, J.M. 1984. Snow stratigraphic investigations at Dome C, East Antarctica. Ohio State Univ. Inst. Polar Stud. Rep. 78.

Palais, J.M., I.M. Whillans, and C. Bull. 1982. Snow stratigraphic studies at Dome C, East Antarctica: an investigation of depositional and diagenetic processes. Ann. Glaciol., 3, 239-242.

Perla, R. 1982. Preparation of section planes in snow specimens. J. Glaciol., 28(98), 199-204.

Perla, R. and C.S.L. Ommanney. 1985. Snow in strong or weak temperature gradients. Part 1. Experiments and qualitative observations. Cold Reg. Sci. Technol., 11(1), 23-35.

Picciotto, E., G. Crozaz, and W. de Breuck. 1971. Accumulation on the South Pole-Queen Maud Land traverse, 1964-1968. In Crary, A.P., ed. Antarctic snow and ice studies II. Washington, DC, American Geophysical Union, 257-315. (Antarct. Res. Ser. 16.)

Robin, G. de Q. 1983. General glaciology. In Robin, G. de Q., ed. The climatic record in polar ice sheets. Cambridge, etc., Cambridge University Press, 94-97.

Sommerfeld, R.A. 1983. A branch grain theory of temperature gradient metamorphism in snow. J. Geophys. Res., 88(C2), 1484-1494.

Sorge, E. 1935. Glaziologische Untersuchungen in Eismitte. In Wissenschaftliche Ergebnisse der Deutschen Grönland-Expedition Alfred Wegener 1929 und 1930/1931. Bd. 3. Glaziologie. Leipzig, Brockhaus, 62-270.

Underwood, E.E. 1970. Quantitative stereology. Reading, MA, Addison-Wesley Publishing Co.

Weller, G. 1969. The heat and mass balance of snow dunes on the central Antarctic plateau. J. Glaciol., 8(53), 277-284.

Weller, G. and P. Schwerdtfeger. 1970. Thermal properties and heat transfer processes of the snow of the central Antarctic plateau. International Association of Scientific Hydrology Publication 86 (ISAGE), 284-298.

Whillans, I.M., R.A. Bindschadler, and S. Shabtaie. 1988. Mass balance of Ice Stream B, West Antarctica. Ann. Glaciol., 11. 